\title{
Structure, Function, and Pharmacology of NMDA Receptor Channels
}

\author{
V. VYKLICKY ${ }^{1}$, M. KORINEK ${ }^{1}$, T. SMEJKALOVA ${ }^{1}$, A. BALIK ${ }^{1}$, B. KRAUSOVA ${ }^{1}$, \\ M. KANIAKOVA ${ }^{1}$, K. LICHNEROVA ${ }^{1}$, J. CERNY ${ }^{1}$, J. KRUSEK ${ }^{1}$, I. DITTERT ${ }^{1}$, \\ M. HORAK ${ }^{1}$, L. VYKLICKY ${ }^{1}$
}

${ }^{1}$ Department of Cellular Neurophysiology, Institute of Physiology Academy of Sciences of the Czech Republic, Prague, Czech Republic

Received September 15, 2013

Accepted October 2, 2013

\section{Summary}

NMDA receptors have received much attention over the last few decades, due to their role in many types of neural plasticity on the one hand, and their involvement in excitotoxicity on the other hand. There is great interest in developing clinically relevant NMDA receptor antagonists that would block excitotoxic NMDA receptor activation, without interfering with NMDA receptor function needed for normal synaptic transmission and plasticity. This review summarizes current understanding of the structure of NMDA receptors and the mechanisms of NMDA receptor activation and modulation, with special attention given to data describing the properties of various types of NMDA receptor inhibition. Our recent analyses point to certain neurosteroids as NMDA receptor inhibitors with desirable properties. Specifically, these compounds show use-dependent but voltage-independent block, that is predicted to preferentially target excessive tonic NMDA receptor activation. Importantly, neurosteroids are also characterized by use-independent unblock, compatible with minimal disruption of normal synaptic transmission. Thus, neurosteroids are a promising class of NMDA receptor modulators that may lead to the development of neuroprotective drugs with optimal therapeutic profiles.

\section{Key words}

Glutamate receptor • NMDA receptor • Ion channel • Channel blocker $\bullet$ Pharmacology $\bullet$ Synaptic transmission

\section{Corresponding author}

L. Vyklický, Institute of Physiology AS CR, Vídeňská 1083, 14220 Prague 4, Czech Republic. Fax: (420) 24106 2488. E-mail: vyklicky@biomed.cas.cz

\section{Introduction}

Synaptic transmission is central to the ability of the nervous system to process and store information. Synapses are specialized contacts between neurons, where the release of neurotransmitter by the presynaptic neuron activates neurotransmitter receptors on the membrane of the postsynaptic neuron. Excitatory synaptic transmission in the mammalian brain is mediated primarily by the amino acid glutamate, activating two different groups of glutamate receptors: ionotropic and metabotropic. Ionotropic glutamate receptors are ligand-gated ion channels further divided with respect to their pharmacological properties into the following sub-groups: GluA (AMPA, 2-amino-3-3hydroxy-5-methyl-isoxazol-4-yl propanoic acid), GluK (kainate), GluN (NMDA, N-Methyl-D-aspartic acid), and GluD $(\delta)$ receptors. Properties of all ionotropic glutamate receptors have been recently reviewed in detail by Traynelis et al. (2010).

NMDA receptors in particular have received much attention over the last few decades, due to their key role in many types of neural plasticity on the one hand, and their involvement in neuronal excitotoxicity on the other hand. An important goal of much recent research is to identify clinically relevant NMDA receptor antagonists capable of preferentially blocking excitotoxic NMDA receptor activation without interfering with NMDA receptor function needed for normal synaptic transmission and plasticity. Here we summarize current understanding of the structure of NMDA receptors and 
the mechanisms of NMDA receptor activation and modulation by various endogenous and exogenous agents. Special attention is given to data describing the properties of various types of NMDA receptor inhibition, aiming to characterize NMDA receptor blockers with optimal therapeutic profiles.

\section{Structure and gating of NMDA receptors}

The family of NMDA receptors consists of three different subunits termed GluN1-3. Posttranscriptional RNA processing of GluN1 subunits gives rise up to eight different splice variants (Moriyoshi et al. 1991, Sugihara et al. 1992, Zukin and Bennett 1995). GluN2 and N3 subunits are encoded by four (GluN2A-D) and two
(GluN3A and B) genes respectively (Monyer et al. 1992). Functional NMDA receptors are heterotetramers containing two obligatory GluN1 subunits in combination with two GluN2 and/or GluN3 subunits (Monyer et al. 1992, Ulbrich and Isacoff 2008). All subunits have a significant level of homology and are highly related in structure, with a conserved domain organization. An extracellular amino-terminal domain (ATD) is linked to an extracellular ligand binding domain (LBD), which in turn is connected to a transmembrane domain (MD) forming the ion channel. The transmembrane helices in turn communicate with an intracellular carboxy-terminal domain (CTD) (Fig. 1) - reviewed in Traynelis et al. (2010).

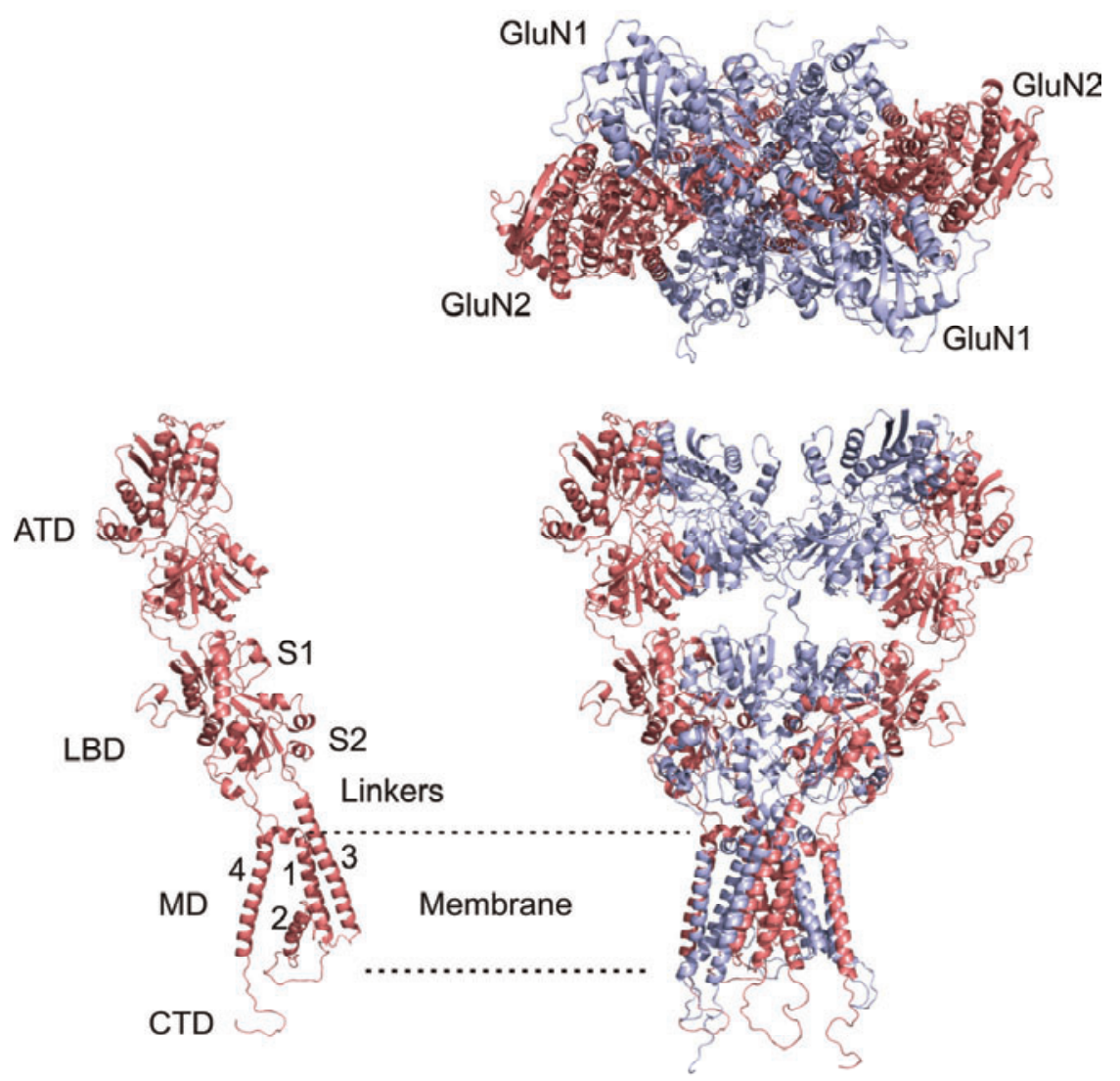

Fig. 1. Right. Homology model of tetrameric GluN1/GluN2 receptor. Top view illustrates currently predicted GluN1 (in gray) - GluN2 (in red) heterodimeric arrangement of subunits. Left. Domain organization of a single glutamate receptor subunit. Two extracellular clamshell-like domains - the amino-terminal (ATD) and the ligand binding domain (LBD) composed of two lobes (upper S1 and lower S2) - are connected to the ion channel formed by four membrane helices (MD) which communicate with the intracellular carboxy-terminal domain (CTD).

Specific functional properties determining the role of the receptor in signal transduction are determined by the mechanism of gating and by the structural features that form the ion channel. The majority of crystallographic and functional data were acquired on the AMPA and kainate types of glutamate receptors (Armstrong and Gouaux 2000, Mayer 2005). These data suggest how the ligand binding domain communicates through short linkers to the ion channel-forming helices.
The current model of channel gating proposes three sequential steps: a) ligand binding into its pocket, b) conformational changes resulting in the closing of the clamshell-like LBD, c) the propagation of these changes leading to channel opening (Mayer and Armstrong 2004, Mayer 2006). These gating principles have been corroborated for NMDA receptors, where the simultaneous presence of two different ligands is required for the activation of a typical GluN1/GluN2 receptor 
(Furukawa et al. 2005). The LBD is composed of two domains. The upper domain S1 forms a tight interface in contact with the second upper domain in a dimer of two LBDs. This arrangement keeps both S1 domains fairly rigid. In contrast, the bottom domains S2 are without a visible dimerization contact and are relatively mobile (Sobolevsky et al. 2009). This mobility feature became apparent in the comparison of AMPA LBD dimer crystal structures binding different full and partial agonists or antagonists, in which the binding pocket closure induced movement of the bottom domains whereas the interface and the position of the upper domains was constant (Madden 2002, Midgett et al. 2012). The ligand-induced movement of the bottom domains immediately impacts on the linker regions connected to the ion channelforming helices. The structural determinants and flexibility of the LBD-MD linkers have a significant role in shaping the mode of gating. Their function is especially fascinating with respect to the change in the symmetry in this region where the LBD 2-fold symmetry is switched to the 4-fold symmetry of the ion channel (Sobolevsky et al. 2009).

In the membrane, three helices (M1, 3 and 4) are linked to the LBD. M3 and the pore forming re-entrant loop M2 are central to channel gating. M3 contains the most conserved region (SYTANLAAF) among glutamate-gated ion channels (Chiu et al. 1999). Many studies employing mutagenesis have described the importance of this region for channel function. Particularly clear evidence came from the lurcher mutant of glutamate receptor delta (GluD2) where a mutation of the third alanine to threonine in the SYTANLA $\underline{\mathbf{A}} \mathrm{F}$ motif created a constitutively active mutant (Zuo et al. 1997). Additional experiments based on substituted cysteines accessible during the channel opening revealed considerable rearrangement of M3 during channel gating (Sobolevsky et al. 2002, 2007). Despite recent progress in transmembrane protein crystallography, we still do not have accurate data to fully delineate the mode of gating. However, structural similarity between the glutamate receptor channel and the potassium channel, together with the availability of potassium channel structures in open and closed states (Jiang et al. 2002, Long et al. 2007) allow us to propose that the MD gate is open through the rotation and side movement of M3 away from the axis of the pore formed by the re-entrant loop M2 (Sobolevsky et al. 2009). The function of pre-M1, M1 and M4 helices is not well understood. Mutation cycle studies show modulating effects of these structures on the mode of gating (Villarroel et al. 1998, Ogden and Traynelis 2013).

In the process of gating, the rearrangement of M3 opens access to the central cavity. The central channel cavity terminates with the ion selective pore, which determines the fundamental properties of the channel - ion permeation and unitary conductance. The tip of the M2 loop contains a critical QRN site that primarily determines the calcium permeability of the channel. AMPA and kainate receptors genetically encoding the amino acid glutamine are calcium permeable (Burnashev et al. 1992a, Kohler et al. 1993). In GluA2 and GluK1/2 subunit mRNAs, posttranscriptional AtoI RNA editing results in the glutamine residue being replaced with arginine, forming calcium impermeable ion channels (Lomeli et al. 1994). In contrast, this site is occupied by asparagine in all GluN subunits leading to high calcium permeability, a hallmark feature of NMDA receptors (Burnashev et al. 1992b).

\section{Activation of NMDA receptors}

The activation of NMDA receptors composed of GluN1/GluN2 subunits requires two molecules of coagonist glycine (Johnson and Ascher 1987, Kleckner and Dingledine 1988) and two molecules of agonist glutamate (Watkins and Evans 1981, Patneau and Mayer 1990, Clements and Westbrook 1991). NMDA receptors composed of GluN1/GluN3 require only glycine for activation (Chatterton et al. 2002, Pachernegg et al. 2012). Since GluN1/GluN2 receptors appear to be physiologically more important, GluN1/GluN3 receptors will not be described further. GluN3 subunit-containing receptor properties are reviewed in Pachernegg et al. (2012).

Glycine is naturally occurring in the extracellular environment of the nervous system (cerebrospinal fluid contains $4.2 \pm 1.6 \mu \mathrm{M}$ of glycine; Iijima et al. 1978). Since the EC50 for glycine acting as a coagonist at GluN1/GluN2 receptors is $\sim 1 \mu \mathrm{M}$, most of its binding sites are naturally occupied. Several other molecules can activate NMDA receptors as coagonists e.g. D-serine (0.65), L-serine (77), D-alanine (0.89), L-alanine (36). Numbers in parentheses show the $\mathrm{EC}_{50}$ value in $\mu \mathrm{M}$ for each coagonist as determined for GluN1/GluN2B NMDA receptors (Chen et al. 2008). Recently, D-serine has been described as the main NMDA receptor coagonist at synapses while glycine is the coagonist of extrasynaptic NMDA receptors (Papouin 
et al. 2012).

Glutamate as the major excitatory neurotransmitter in central nervous system (CNS) is released from presynaptic terminals of glutamatergic synapses and activates NMDA receptors by occupying two binding sites localized at the LBD of GluN2 subunits. NMDA receptor agonists and partial agonists include: L-glutamate (2.9), D-glutamate (160), NMDA (30), N-methyl-L-aspartate (127), D-aspartate (10), L-aspartate (14) and many others. Numbers in parentheses show the $\mathrm{EC}_{50}$ value in $\mu \mathrm{M}$ for each agonist as determined for GluN1/GluN2B NMDA receptors (Erreger et al. 2007).

The spatiotemporal profile of extracellular glutamate concentration determines the specific pattern of NMDA receptor activation. Synaptically released glutamate reaches a peak cleft concentration of $\sim 1 \mathrm{mM}$ and then it is rapidly removed by diffusion and uptake, with a time constant of $\sim 1 \mathrm{~ms}$ (reviewed by Bergles et al. 1999). This brief glutamate concentration transient results in phasic activation of NMDA receptors, contributing to normal synaptic transmission. The highly efficient glutamate uptake system normally maintains baseline extracellular glutamate concentration in the low nM range (Herman and Jahr 2007, Herman et al. 2011), preventing substantial NMDA receptor activation at rest. Importantly, many acute and chronic neurological diseases are associated with dysregulated glutamate release/uptake (Mattson 2003, Nyitrai et al. 2006), resulting in prolonged elevation of extracellular glutamate concentration, likely reaching $\mu \mathrm{M}$ values (Phillis and O'Regan 2003, Heinrich et al. 2012). Such high levels of ambient glutamate cause excessive tonic activation of receptors, inducing excitotoxicity.

Upon coagonist and agonist binding, ion channel opens selectively for cations (especially $\mathrm{Na}^{+}, \mathrm{K}^{+}$and $\mathrm{Ca}^{2+}$ ). The extracellular concentration of $\mathrm{Na}^{+}$is typically $145-150 \mathrm{mM}$ while that of $\mathrm{Ca}^{2+}$ is $1-1.5 \mathrm{mM}$ (Vander et al. 2001). Since relative permeability of ion channel for $\mathrm{Ca}^{2+}$ is 10 times higher compared to $\mathrm{Na}^{+}$(Mayer and Westbrook 1987), significant amount of calcium gets into neurons. Calcium is a key intracellular signaling molecule involved in many types of neural plasticity (Malenka and Nicoll 1999), but it is also a key mediator of excitotoxic cell death if present in excess (Mattson 2003).

Figure 2 panels $\mathrm{A}$ and $\mathrm{B}$ illustrate tonic and phasic NMDA receptor activation, respectively. Figure 2C presents a basic kinetic scheme of NMDA receptor activation, showing the receptor (R) binding the agonist (A), as well as receptor opening (O), desensitization (D), and calcium-dependent desensitization (I). The entry to the I state is induced by $\mathrm{Ca}^{2+}$ ions entering neurons through the activated NMDA receptors. As a result, the extent of this calciumdependent desensitization depends on the extracellular calcium concentration (Clark et al. 1990, Vyklicky 1993). NMDA receptor responses may also exhibit glycinedependent desensitization, caused by a lowered affinity of glycine for its binding site when agonist molecules are bound to the receptor (Mayer et al. 1989, Benveniste et al. 1990). Saturating concentrations of glycine eliminate this effect.

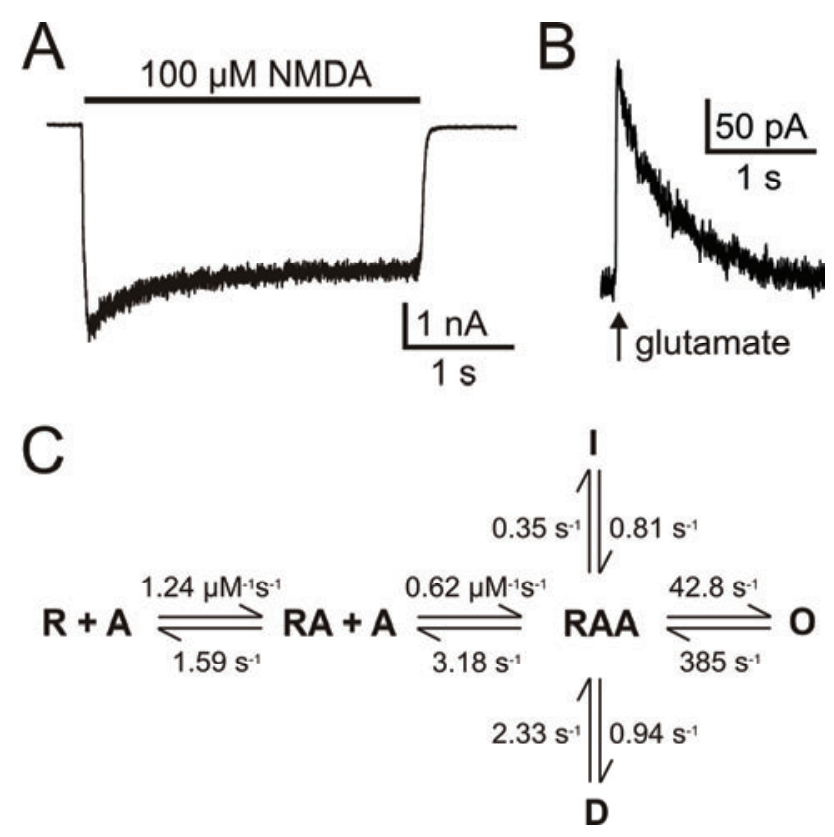

Fig. 2. Figure 2A illustrates tonic NMDA receptor activation by NMDA applied for $3 \mathrm{~s}$. After a fast onset, this response exhibits desensitization which typically has a double-exponential time course. Deactivation occurs after NMDA is washed off and its time course also has a fast and a slow component. Figure 2B illustrates phasic NMDA receptor activation by synaptically released glutamate. Following a rapid onset, the NMDA receptor response deactivates with double-exponential kinetics (Korinek et al. 2010). Figure 2C presents a basic kinetic scheme of NMDA receptor activation (Lester and Jahr 1992). The rate constants shown were determined for HEK cells expressing recombinant GluN1-1a/GluN2B receptors activated by glutamate at $25^{\circ} \mathrm{C}$ with $0.5 \mathrm{mM}$ extracellular calcium (Cais et al. 2008). Their values are different for other agonists, temperatures, $\mathrm{Ca}^{2+}$ concentrations and subunit compositions of NMDA receptors.

Even though the kinetic scheme in Figure $2 \mathrm{C}$ is sufficient to describe whole-cell NMDA receptor responses (to either phasic or tonic activation), a more complicated situation occurs when single channel 
openings in excised patches are to be described. Millions of ion channel openings are typically analyzed for open time and close time histograms. These analyses have not yet produced a unanimous kinetic scheme of single channel gating. They revealed that ion channel opening does not occur directly from the RAA state but rather there is a fine structure of 3 to 4 closed states and one or two open states behind the RAA state (Banke and Traynelis 2003, Popescu and Auerbach 2003, Erreger et al. 2005, Dravid et al. 2008, Amico-Ruvio and Popescu 2010).

\section{NMDA receptor pharmacology}

NMDA receptor activity can be modulated both positively and negatively. Positive modulators increase the maximal response or the affinity for the agonist, but have a binding site that is different from the agonist binding site. Some endogenous compounds such as polyamines can potentiate the activity of GluN2Bcontaining receptors (Williams et al. 1990) by increasing the glycine sensitivity of the receptor (Traynelis et al. 1995). It is assumed that polyamines bind at the interface between ATDs of GluN1 and GluN2B subunits (Mony et al. 2011). Furthermore, certain neurosteroids may positively modulate the function of NMDA receptors. For example, pregnenolone sulfate (PS) potentiates GluN2A or GluN2B-containing receptors (Wu et al. 1991, Malayev et al. 2002, Horak et al. 2006) by increasing the open channel probability (Horak et al. 2004), with the potentiating ability of PS dependent on receptor phosphorylation (Petrovic et al. 2009). Recently, Mullasseril et al. (2010) identified a highly selective allosteric potentiator (3-chlorophenyl)(6,7-dimethoxy-1((4- methoxyphenoxy)methyl)3,4-dihydroisoquinolin$2(1 \mathrm{H})$-yl)methanone (CIQ), that enhances the activity of GluN2C or GluN2D subunit-containing recombinant receptors by increasing channel opening frequency.

Antagonists may be sorted according to their place of action: at the agonist binding site (competitive), within the ion channel pore (channel blockers), or at specific modulation sites (noncompetitive). Competitive antagonists compete with the agonist for the binding site, but do not activate the receptor. One of the first described competitive antagonists at the glutamate binding site was D-2-amino-5-phosphonovalerate (DAPV), which is highly selective for NMDA receptors over AMPA and kainate receptors (Watkins and Evans
1981). However, D-APV displayed a low selectivity (less than 10-fold) for different GluN2 subunits (Feng et al. 2005). Although some antagonists with a bulky hydrophobic substituent, such as $\left(2 \mathrm{R}^{*}, 3 \mathrm{~S}^{*}\right)-1$ (phenanthrene-3-carbonyl) piperazine-2,3-dicarboxylic acid (UBP141) or $\left(2 \mathrm{R}^{*}, 3 \mathrm{~S}^{*}\right)$-1-(9-bromophenanthrene-3-carbonyl)piperazine-2,3-dicarboxylic acid (UBP145) show an improved selectivity for GluN2D subunit (Morley et al. 2005, Costa et al. 2009), in general, subunit selectivity for competitive antagonists is difficult to achieve due to the high homology among the LBDs of the different GluN2 subunits (Kinarsky et al. 2005).

Some dissociative anesthetics (e.g. phencyclidine or ketamine), as well as a widely-used inhibitor dizocilpine maleate (MK-801), act as potent channel blockers (Wong et al. 1986, Anis et al. 1990, Lodge and Johnson 1990). Blockade of the ion channel is voltage- and use-dependent, which means that the block of the channel requires previous receptor activation. Because of this, the inhibition by channel blockers is slow in onset and increases with the probability of channel opening. A low-affinity channel blocker memantine (Kalia et al. 2008), is better tolerated clinically, probably due to its fast dissociation out of the channel upon receptor inactivation, resulting in minimal interference with normal synaptic transmission (Chen and Lipton 2005). The ion channel region is highly conserved across the different receptor subunits, which is likely the reason for the low subtype selectivity (less than 10-fold) of the various channel blockers (Dravid et al. 2007), but it was shown that physiological levels of $\mathrm{Mg}^{2+}$ decrease memantine inhibition of GluN2A or GluN2B-containing receptors nearly 20 -fold, so the selectivity for NMDA receptors containing GluN2C and GluN2D subunits increases up to 10-fold (Kotermanski and Johnson 2009).

The first subunit-specific NMDA receptor antagonist discovered was ifenprodil, representing a class of noncompetitive, voltage- and use-independent inhibitors of NMDA receptors (Legendre and Westbrook 1991). Ifenprodil inhibits GluN1/GluN2B receptors with a 200 - to 400 -fold higher affinity than any other combination of GluN1/GluN2 subunits (Williams 1993). Crystallographic studies revealed that the binding site for ifenprodil is at the interface between ATDs of the GluN1/GluN2B heterodimers (Karakas et al. 2011). In recent years, novel noncompetitive antagonists with distinctive GluN2 
subunit selectivity have been described. From a series of sulfonamide derivates, 3-chloro-4-fluoro- $N$-[(4-[(2(phenylcarbonyl)hydrazino)carbonyl]phenyl)methyl]benzenesulfonamide (TCN-201) shows a high selectivity for GluN2A-containing receptors (Bettini et al. 2010). TCN-201 acts as a negative allosteric modulator of glycine binding and the binding site of TCN-201 is presumed to be located at the interface between LBDs of GluN1 and GluN2A subunits (Hansen et al. 2012).

A novel class of compounds selective for GluN2C or GluN2D subunit-containing receptors has recently been identified. (E)-4-(6-methoxy-2(3-nitrostyryl)-4-oxoquinazolin-3(4H)-yl)-benzoic acid (QNZ46) inhibits NMDA receptor activity in a noncompetitive, voltage-independent manner (Mosley et al. 2010). However, the mechanism of QNZ46 action is unusual in that the inhibition by QNZ46 is usedependent and requires the presence of glutamate (Hansen and Traynelis 2011). The study of chimeric GluN2A/GluN2D receptors and site-directed mutagenesis revealed that specific amino acid residues in the S2 portion of the GluN2 subunit LBD are critical for antagonist activity (Hansen and Traynelis 2011). In addition, the S2 region has been implicated in the modulation of NMDA receptors by structurally unrelated compounds such as DQP1105 (Acker et al. 2011), phenanthrene and carboxylated naphthalene derivates (Costa et al. 2010, 2012), as well as endogenous sulfated neurosteroids (Jang et al. 2004, Petrovic et al. 2005, Horak et al. 2006), that can display both potentiating and inhibiting activity with various degrees of subunit selectivity. These facts indicate that the S2 region plays an important role in controlling channel gating.

Endogenous neurosteroid pregnanolone sulfate (3 $\alpha 5 \beta S$ S) inhibits NMDA receptor activity in a voltageindependent but a use-dependent manner by reducing the open channel probability, and it has a two times lower effect on receptors containing the GluN2A or GluN2B subunits compared to the GluN2C or GluN2D subunits (Petrovic et al. 2005). It has been shown that $3 \alpha 5 \beta \mathrm{S}$ acts solely from the extracellular side of the NMDA receptor (Park-Chung et al. 1997, Petrovic et al. 2005), and our recent results indicate the importance of membrane for the inhibitory effects of neurosteroids (Borovska et al. 2012). However, the identification of the binding site for steroids with the inhibitory action on NMDA receptors has so far failed.

\section{Inhibition of tonically and phasically activated NMDA receptors}

As mentioned above, excessive activation of NMDA receptors leads to excitotoxic cell death and plays a crucial role in many acute and chronic neurological disorders. Extensive effort has been made in the last 20 years to develop NMDAR antagonists which could be used as neuroprotective drugs. However, most of the compounds tested so far have failed in clinical trials (Kalia et al. 2008). A common side effect of NMDAR antagonists is their psychomimetic effect caused by the distortion of normal synaptic transmission. How to fulfill these two demands - block the excessive NMDA receptor activation and, simultaneously, leave the normal NMDA receptormediated synaptic transmission intact? The answer could be hidden in the pattern of channel activation by synaptically released versus pathologically elevated glutamate. While during synaptic transmission NMDA receptors are briefly activated by a saturating $\sim 1 \mathrm{mM}$ concentration of glutamate (phasic activation, see above), excitotoxicity is induced by prolonged activation of NMDA receptors by $\mu \mathrm{M}$ concentrations of glutamate that may range widely depending on the type of the pathology (tonic activation).

We have tested an endogenous neurosteroid $3 \alpha 5 \beta S$ for its ability to preferentially block tonically over phasically activated recombinant GluN1-1a/GluN2B receptors and we found that the $\mathrm{EC}_{50}$ for tonically activated receptors is approximately 2 times lower than the $\mathrm{EC}_{50}$ for peak inhibition of phasically activated receptors (unpublished data). These data are comparable with the published results for memantine, a drug approved for treatment of Alzheimer's disease, which does not exert any psychomimetic side effects (Kornhuber and Weller 1997, Xia et al. 2010).

To determine which features of NMDA receptor antagonism are crucial for a high ratio of tonic over phasic inhibition, we used Gepasi 3.30 software to simulate inhibitory effects of some common types of NMDA receptor inhibitors for different channel activation patterns. The types of inhibition considered were: competitive inhibition, non-competitive useindependent inhibition, open-channel blockade, and neurosteroid inhibition. For the open-channel blockade, the "trapping" type means, that the channel may close and consequently allow the agonist to dissociate while 
the blocker is bound inside the channel. The term "foot in the door" is used for open channel blockers which prevent channel closing and agonist dissociation while bound inside the channel. A simplified kinetic model activated by two molecules of glutamate without any desensitized states was used. The rate constants for GluN1-1a/GluN2B at $25^{\circ} \mathrm{C}$ were used, based on our previous data (Cais et al. 2008). For the rate constants of inhibitor binding and unbinding to the receptor, we used the data for D-APV (a competitive inhibitor, Benveniste and Mayer 1991), ifenprodil (a noncompetitive use-independent inhibitor, AmicoRuvio et al. 2012), memantine (an open-channel blocker, the same rate constants were used for both the "trapping" and the "foot-in-the-door" types of open channel blockade, Johnson and Kotermanski 2006) and the neurosteroid $3 \alpha 5 \beta \mathrm{S}$ (a noncompetitive usedependent inhibitor, Papouin et al. 2012).

Tonic inhibition in Figure 3 shows the degree of inhibition for various combinations of glutamate and inhibitor concentrations. The effect of glutamate concentration on the inhibitory effect varies from the competitive inhibitor which has no inhibitory effect for high glutamate concentrations, to the noncompetitive use-independent inhibitor and the open-channel blocker "trapping" where there is almost no effect of glutamate concentration on the degree of inhibition, to the openchannel blocker "foot in the door" and the neurosteroid, where the degree of inhibition is higher for higher glutamate concentrations. Phasic inhibition in Figure 3 displays the time course of simulated synaptic transmission responses during the ongoing presence of an inhibitor. The insets show the dose-response curves for synaptic transmission, calculated from the peak and from the area (charge transfer) of the synaptic current. $\Delta$ Inhibition in Figure 3 shows the difference between the degree of tonic and phasic inhibition. Since the goal is to leave phasically activated receptors unaffected while inhibiting tonically activated receptors as much as possible, neither the competitive inhibitor nor the useindependent inhibitor is useful. The best results are obtained for both types of open channel blockers and the neurosteroid - note that these three models represent use-dependent blockers.

The tonic/phasic ratio, however, is not the only requirement for an inhibitor with an expected positive therapeutic profile. Due to the fact that the inhibitor is present in the brain throughout the treatment, it is necessary to use an inhibitor which has a useindependent unblock or must be able to escape the channel during cell depolarization due to its fast unblocking rate and its voltage-dependency (Gilling et al. 2009). This would provide a chance to a synaptic receptor to be activated again if it is "accidentally" blocked, e.g. during a fast train of action potentials. For this reason, a "trapping" open-channel blocker is not a good choice for an ideal NMDAR blocker. The best choice appears to be a "foot in the door" open-channel blocker or a neurosteroid. But there is an additional difficulty: a typical feature of open-channel blockers is that the inhibition is voltage-dependent. This means that they lose their inhibitory effect on long-term depolarized cells - such as tonically excited cells. In contrast, neurosteroids are voltage-independent NMDAR blockers and act to the same extent at all physiological membrane potentials (Papouin et al. 2012).

The results of our modeling indicate, that the neurosteroid $3 \alpha 5 \beta \mathrm{S}$ or its synthetic analogs with usedependent but voltage-independent block and useindependent unblock are a promising class of NMDAR modulators and could lead to the prospective development of new neuroprotective drugs with desirable therapeutic profiles.

\section{Conclusion}

Results of recent work using advanced experimental and computational techniques greatly improve our understanding of how the NMDA receptor is organized and inform the search for modulators with specific positive or negative effects. One important challenge is to identify substances capable of differential modulation of tonically vs. phasically activated receptors, reducing neurodegeneration caused by pathologically elevated extracellular glutamate, while leaving normal synaptic transmission intact.

Our recent analysis suggests that certain neurosteroids are NMDA receptor inhibitors with the desired properties, showing use-dependent but voltageindependent block and use-independent unblock, in contrast to open channel blockers that are voltage dependent. Thus, neurosteroids are a promising class of NMDA receptor modulators that may lead to the development of neuroprotective drugs with optimal therapeutic profiles. 

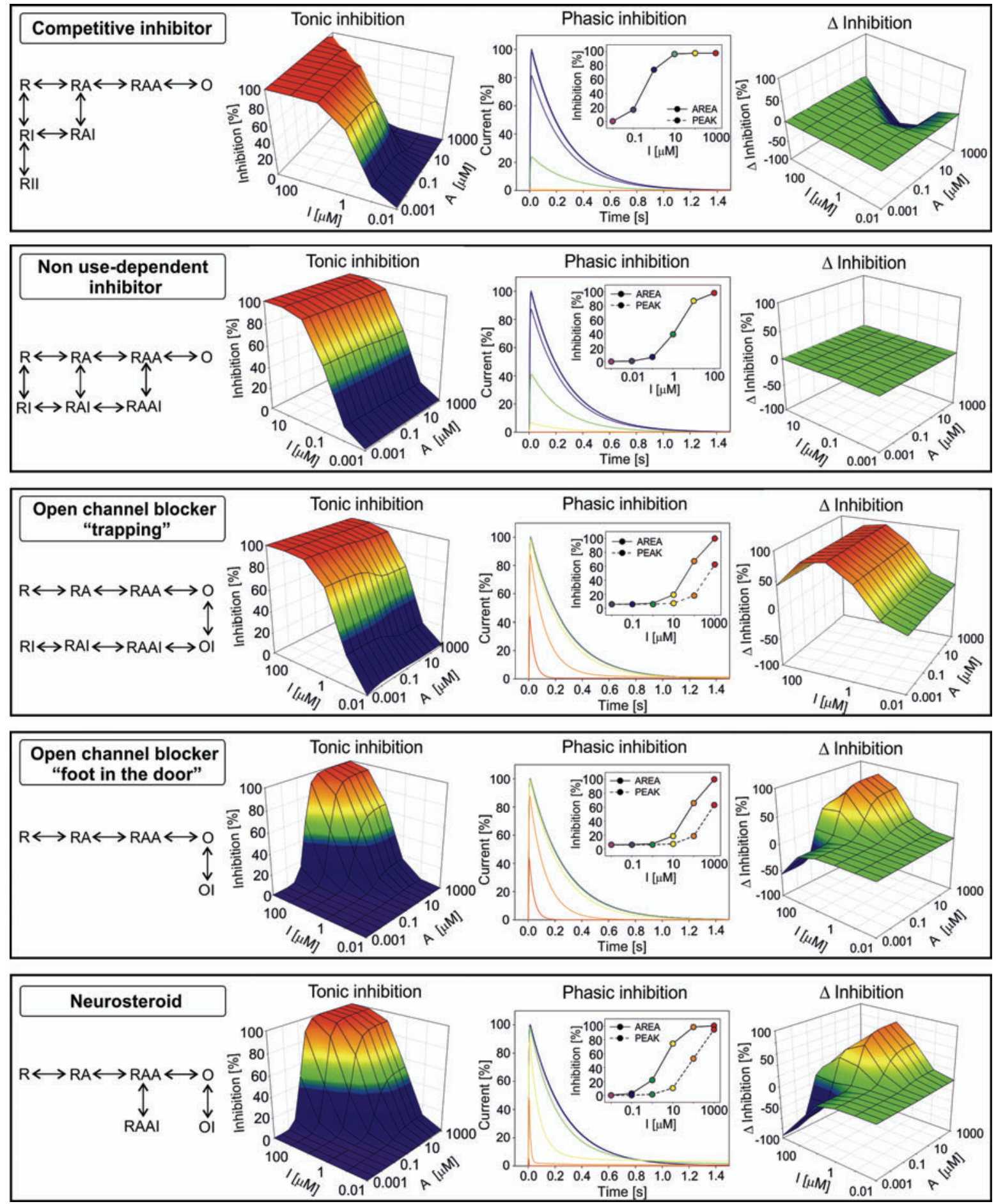

Fig. 3. Simulation of inhibitory effect of some common types of NMDA receptor inhibitors. Different ion channel activation patterns are compared. For each type of inhibitor, the kinetic scheme of inhibitory action of inhibitor "I" on the receptor "R" activated by two agonists " $\mathrm{A}$ " (in this case glutamate) is shown first. Note that desensitization states were omitted and no membrane potential changes were applied during simulations. Next to the kinetic scheme is a plot of the degree of steady-state inhibition induced by the inhibitor acting on the receptor activated by various concentrations of the agonist ("Tonic inhibition"). The "Phasic inhibition" graph shows the kinetic profile of a simulated postsynaptic current $(1 \mathrm{mM}$ Glutamate for $5 \mathrm{~ms})$ in the ongoing presence of various concentrations of the inhibitor. The inset shows the dose response curves for postsynaptic current inhibition calculated from the peak (maximum current) and the area (total charge transfer) of the current. The graph " $\Delta$ Inhibition" refers to the difference in the degree of inhibition between tonically and phasically activated receptors $(\Delta$ Inhibition $=$ Tonic inhibition - Phasic inhibition (peak)). That means that ideal inhibitor should have maximal tonic inhibition and simultaneously minimal phasic inhibiton, thus we are looking for maximal $\Delta$ Inhibition indicated by red color. Rate constants were as follows [in $\mathrm{s}^{-1}$ and $\mu \mathrm{M}^{-1} \cdot \mathrm{s}^{-1}$ ]: R-RA: $\mathrm{k}_{\text {on }}=0.616, \mathrm{k}_{\text {off }}=2.166 ;$ RAA-O: $\mathrm{k}_{\text {on }}=42.77 \mathrm{k}_{\text {off }}=384.9$; competitive inhibitor, $k_{\text {on }}=22.2, k_{\text {off }}=19.4$; noncompetitive use-independent inhibitor: $k_{\text {on }}=1400, k_{\text {off }}=90$; open-channel blocker: $k_{\text {on }}=0.5$, $\mathrm{k}_{\text {off }}=0.25$; neurosteroid: RAA-RAAI: $\mathrm{k}_{\text {on }}=0.98, \mathrm{k}_{\text {off }}=0.82, \mathrm{O}-\mathrm{OI}: \mathrm{k}_{\text {on }}=1.6, \mathrm{k}_{\text {off }}=7.0$. Except for the neurosteroid which has different binding constants to different states of the receptor, the rest of the inhibitors were taken to bind to all states in the kinetic scheme with the same rate constants. 


\section{Conflict of Interest}

There is no conflict of interest.

\section{Acknowledgements}

This work was supported by the Grant Agency of the Czech Republic (P303/11/0075, P304/12/G069, P303/12/1464, P303/11/P391), Marie Curie International Reintegration Grant (PIRG-GA-2010-276827; M. Horak)
TE 01020028, Research Project RVO:67985823 and CZ.1.07/2.3./00/30.0025, by the project BIOCEV Biotechnology and Biomedicine Centre of the Academy of Sciences and Charles University (CZ.1.05/1.1.00/02.0109), from the European Regional Development Fund and by the Grant Agency of Charles University (GAUK 800313).

\section{References}

ACKER TM, YUAN H, HANSEN KB, VANCE KM, OGDEN KK, JENSEN HS, BURGER PB, MULLASSERIL P, SNYDER JP, LIOTTA DC, TRAYNELIS SF: Mechanism for noncompetitive inhibition by novel GluN2C/D N-methyl-D-aspartate receptor subunit-selective modulators. Mol Pharmacol 80: 782-795, 2011.

AMICO-RUVIO SA, POPESCU GK: Stationary gating of GluN1/GluN2B receptors in intact membrane patches. Biophys J 98: 1160-1169, 2010.

AMICO-RUVIO SA, PAGANELLI MA, MYERS JM, POPESCU GK: Ifenprodil effects on GluN2B-containing glutamate receptors. Mol Pharmacol 82: 1074-1081, 2012.

ANIS N, SHERBY S, GOODNOW R JR, NIWA M, KONNO K, KALLIMOPOULOS T, BUKOWNIK R, NAKANISHI K, USHERWOOD P, ELDEFRAWI A, ELDEFRAWI M: Structure-activity relationships of philanthotoxin analogs and polyamines on N-methyl-D-aspartate and nicotinic acetylcholine receptors. J Pharmacol Exp Ther 254: 764-773, 1990.

ARMSTRONG N, GOUAUX E: Mechanisms for activation and antagonism of an AMPA-sensitive glutamate receptor: crystal structures of the GluR2 ligand binding core. Neuron 28: 165-181, 2000.

BANKE TG, TRAYNELIS SF: Activation of NR1/NR2B NMDA receptors. Nat Neurosci 6: 144-152, 2003.

BENVENISTE M, MAYER ML: Kinetic analysis of antagonist action at N-methyl-D-aspartic acid receptors. Two binding sites each for glutamate and glycine. Biophys J 59: 560-573, 1991.

BENVENISTE M, CLEMENTS J, VYKLICKY L JR, MAYER ML: A kinetic analysis of the modulation of N-methylD-aspartic acid receptors by glycine in mouse cultured hippocampal neurones. J Physiol 428: 333-357, 1990.

BERGLES DE, DIAMOND JS, JAHR CE: Clearance of glutamate inside the synapse and beyond. Curr Opin Neurobiol 9: 293-298, 1999.

BETTINI E, SAVA A, GRIFFANTE C, CARIGNANI C, BUSON A, CAPELLI AM, NEGRI M, ANDREETTA F, SENAR-SANCHO SA, GUIRAL L, CARDULLO F: Identification and characterization of novel NMDA receptor antagonists selective for NR2A- over NR2B-containing receptors. J Pharmacol Exp Ther 335: 636-644, 2010.

BOROVSKA J, VYKLICKY V, STASTNA E, KAPRAS V, SLAVIKOVA B, HORAK M, CHODOUNSKA H, VYKLICKY L JR: Access of inhibitory neurosteroids to the NMDA receptor. Br J Pharmacol 166: 10691083, 2012.

BURNASHEV N, MONYER H, SEEBURG PH, SAKMANN B: Divalent ion permeability of AMPA receptor channels is dominated by the edited form of a single subunit. Neuron 8: 189-198, 1992a.

BURNASHEV N, SCHOEPFER R, MONYER H, RUPPERSBERG JP, GUNTHER W, SEEBURG PH, SAKMANN B: Control by asparagine residues of calcium permeability and magnesium blockade in the NMDA receptor. Science 257: 1415-1419, $1992 \mathrm{~b}$.

CAIS O, SEDLACEK M, HORAK M, DITTERT I, VYKLICKY L JR: Temperature dependence of NR1/NR2B NMDA receptor channels. Neuroscience 151: 428-438, 2008.

CHATTERTON JE, AWOBULUYI M, PREMKUMAR LS, TAKAHASHI H, TALANTOVA M, SHIN Y, CUI J, TU S, SEVARINO KA, NAKANISHI N, TONG G, LIPTON SA, ZHANG D: Excitatory glycine receptors containing the NR3 family of NMDA receptor subunits. Nature 415: 793-798, 2002. 
CHEN HS, LIPTON SA: Pharmacological implications of two distinct mechanisms of interaction of memantine with N-methyl-D-aspartate-gated channels. J Pharmacol Exp Ther 314: 961-971, 2005.

CHEN PE, GEBALLE MT, KATZ E, ERREGER K, LIVESEY MR, O'TOOLE KK, LE P, LEE CJ, SNYDER JP, TRAYNELIS SF, WYLLIE DJ: Modulation of glycine potency in rat recombinant NMDA receptors containing chimeric NR2A/2D subunits expressed in Xenopus laevis oocytes. J Physiol 586: 227-245, 2008.

CHIU J, DESALLE R, LAM HM, MEISEL L, CORUZZI G: Molecular evolution of glutamate receptors: a primitive signaling mechanism that existed before plants and animals diverged. Mol Biol Evol 16: 826-838, 1999.

CLARK GD, CLIFFORD DB, ZORUMSKI CF: The effect of agonist concentration, membrane voltage and calcium on N-methyl-D-aspartate receptor desensitization. Neuroscience 39: 787-797, 1990.

CLEMENTS JD, WESTBROOK GL: Activation kinetics reveal the number of glutamate and glycine binding sites on the N-methyl-D-aspartate receptor. Neuron 7: 605-613, 1991.

COSTA BM, FENG B, TSINTSADZE TS, MORLEY RM, IRVINE MW, TSINTSADZE V, LOZOVAYA NA, JANE DE, MONAGHAN DT: N-methyl-D-aspartate (NMDA) receptor NR2 subunit selectivity of a series of novel piperazine-2,3-dicarboxylate derivatives: preferential blockade of extrasynaptic NMDA receptors in the rat hippocampal CA3-CA1 synapse. J Pharmacol Exp Ther 331: 618-626, 2009.

COSTA BM, IRVINE MW, FANG G, EAVES RJ, MAYO-MARTIN MB, SKIFTER DA, JANE DE, MONAGHAN DT: A novel family of negative and positive allosteric modulators of NMDA receptors. $J$ Pharmacol Exp Ther 335: 614-621, 2010.

COSTA BM, IRVINE MW, FANG G, EAVES RJ, MAYO-MARTIN MB, LAUBE B, JANE DE, MONAGHAN DT: Structure-activity relationships for allosteric NMDA receptor inhibitors based on 2-naphthoic acid. Neuropharmacology 62: 1730-1736, 2012.

DRAVID SM, ERREGER K, YUAN H, NICHOLSON K, LE P, LYUBOSLAVSKY P, ALMONTE A, MURRAY E, MOSELY C, BARBER J, FRENCH A, BALSTER R, MURRAY TF, TRAYNELIS SF: Subunit-specific mechanisms and proton sensitivity of NMDA receptor channel block. J Physiol 581: 107-128, 2007.

DRAVID SM, PRAKASH A, TRAYNELIS SF: Activation of recombinant NR1/NR2C NMDA receptors. $J$ Physiol 586: 4425-4439, 2008.

ERREGER K, DRAVID SM, BANKE TG, WYLLIE DJ, TRAYNELIS SF: Subunit-specific gating controls rat NR1/NR2A and NR1/NR2B NMDA channel kinetics and synaptic signalling profiles. $J$ Physiol 563: $345-358$, 2005.

ERREGER K, GEBALlE MT, KRISTENSEN A, CHEN PE, HANSEN KB, LEE CJ, YUAN H, LE P, LYUBOSLAVSKY PN, MICALE N, JORGENSEN L, CLAUSEN RP, WYLLIE DJ, SNYDER JP, TRAYNELIS SF: Subunit-specific agonist activity at NR2A-, NR2B-, NR2C-, and NR2D-containing N-methyl-D-aspartate glutamate receptors. Mol Pharmacol 72: 907-920, 2007.

FENG B, MORLEY RM, JANE DE, MONAGHAN DT: The effect of competitive antagonist chain length on NMDA receptor subunit selectivity. Neuropharmacology 48: 354-359, 2005.

FURUKAWA H, SINGH SK, MANCUSSO R, GOUAUX E: Subunit arrangement and function in NMDA receptors. Nature 438: 185-192, 2005.

GILLING KE, JATZKE C, HECHENBERGER M, PARSONS CG: Potency, voltage-dependency, agonist concentration-dependency, blocking kinetics and partial untrapping of the uncompetitive N-methyl-D-aspartate (NMDA) channel blocker memantine at human NMDA (GluN1/GluN2A) receptors. Neuropharmacology 56: 866-875, 2009.

HANSEN KB, TRAYNELIS SF: Structural and mechanistic determinants of a novel site for noncompetitive inhibition of GluN2D-containing NMDA receptors. $J$ Neurosci 31: 3650-3661, 2011.

HANSEN KB, OGDEN KK, TRAYNELIS SF: Subunit-selective allosteric inhibition of glycine binding to NMDA receptors. J Neurosci 32: 6197-6208, 2012.

HEINRICH A, ANDO RD, TURI G, ROZSA B, SPERLAGH B: K+ depolarization evokes ATP, adenosine and glutamate release from glia in rat hippocampus: a microelectrode biosensor study. $\mathrm{Br} J$ Pharmacol 167: 1003-1020, 2012.

HERMAN MA, JAHR CE: Extracellular glutamate concentration in hippocampal slice. J Neurosci 27: 9736-9741, 2007. 
HERMAN MA, NAHIR B, JAHR CE: Distribution of extracellular glutamate in the neuropil of hippocampus. PLoS One 6: e26501, 2011.

HORAK M, VLCEK K, PETROVIC M, CHODOUNSKA H, VYKLICKY L JR: Molecular mechanism of pregnenolone sulfate action at NR1/NR2B receptors. J Neurosci 24: 10318-10325, 2004.

HORAK M, VLCEK K, CHODOUNSKA H, VYKLICKY L JR: Subtype-dependence of N-methyl-D-aspartate receptor modulation by pregnenolone sulfate. Neuroscience 137: 93-102, 2006.

IIJIMA K, TAKASE S, TSUMURAYA K, ENDO M, ITAHARA K: Changes in free amino acids of cerebrospinal fluid and plasma in various neurological diseases. Tohoku J Exp Med 126: 133-150, 1978.

JANG MK, MIERKE DF, RUSSEK SJ, FARB DH: A steroid modulatory domain on NR2B controls N-methyl-Daspartate receptor proton sensitivity. Proc Natl Acad Sci USA 101: 8198-8203, 2004.

JIANG Y, LEE A, CHEN J, CADENE M, CHAIT BT, MACKINNON R: The open pore conformation of potassium channels. Nature 417: 523-526, 2002.

JOHNSON JW, ASCHER P: Glycine potentiates the NMDA response in cultured mouse brain neurons. Nature 325: 529-531, 1987.

JOHNSON JW, KOTERMANSKI SE: Mechanism of action of memantine. Curr Opin Pharmacol 6: 61-67, 2006.

KALIA LV, KALIA SK, SALTER MW: NMDA receptors in clinical neurology: excitatory times ahead. Lancet Neurol 7: 742-755, 2008.

KARAKAS E, SIMOROWSKI N, FURUKAWA H: Subunit arrangement and phenylethanolamine binding in GluN1/GluN2B NMDA receptors. Nature 475: 249-253, 2011.

KINARSKY L, FENG B, SKIFTER DA, MORLEY RM, SHERMAN S, JANE DE, MONAGHAN DT: Identification of subunit- and antagonist-specific amino acid residues in the N-Methyl-D-aspartate receptor glutamatebinding pocket. J Pharmacol Exp Ther 313: 1066-1074, 2005.

KLECKNER NW, DINGLEDINE R: Requirement for glycine in activation of NMDA-receptors expressed in Xenopus oocytes. Science 241: 835-837, 1988.

KOHLER M, BURNASHEV N, SAKMANN B, SEEBURG PH: Determinants of Ca2+ permeability in both TM1 and TM2 of high affinity kainate receptor channels: diversity by RNA editing. Neuron 10: 491-500, 1993.

KORINEK M, SEDLACEK M, CAIS O, DITTERT I, VYKLICKY L JR: Temperature dependence of N-methyl-Daspartate receptor channels and N-methyl-D-aspartate receptor excitatory postsynaptic currents. Neuroscience 165: 736-748, 2010.

KORNHUBER J, WELLER M: Psychotogenicity and N-methyl-D-aspartate receptor antagonism: implications for neuroprotective pharmacotherapy. Biol Psychiatry 41: 135-144, 1997.

KOTERMANSKI SE, JOHNSON JW: Mg2+ imparts NMDA receptor subtype selectivity to the Alzheimer's drug memantine. J Neurosci 29: 2774-2779, 2009.

LEGENDRE P, WESTBROOK GL: Ifenprodil blocks N-methyl-D-aspartate receptors by a two-component mechanism. Mol Pharmacol 40: 289-298, 1991.

LESTER RA, JAHR CE: NMDA channel behavior depends on agonist affinity. $J$ Neurosci 12: 635-643, 1992.

LODGE D, JOHNSON KM: Noncompetitive excitatory amino acid receptor antagonists. Trends Pharmacol Sci 11: 81-86, 1990.

LOMELI H, MOSBACHER J, MELCHER T, HOGER T, GEIGER JR, KUNER T, MONYER H, HIGUCHI M, BACH A, SEEBURG PH: Control of kinetic properties of AMPA receptor channels by nuclear RNA editing. Science 266: 1709-1713, 1994.

LONG SB, TAO X, CAMPBELL EB, MACKINNON R: Atomic structure of a voltage-dependent $\mathrm{K}+$ channel in a lipid membrane-like environment. Nature 450: 376-382, 2007.

MADDEN DR: The structure and function of glutamate receptor ion channels. Nat Rev Neurosci 3: 91-101, 2002.

MALAYEV A, GIBBS TT, FARB DH: Inhibition of the NMDA response by pregnenolone sulphate reveals subtype selective modulation of NMDA receptors by sulphated steroids. Br J Pharmacol 135: 901-909, 2002.

MALENKA RC, NICOLL RA: Long-term potentiation - a decade of progress? Science 285: 1870-1874, 1999.

MATTSON MP: Excitotoxic and excitoprotective mechanisms: abundant targets for the prevention and treatment of neurodegenerative disorders. Neuromolecular Med 3: 65-94, 2003. 
MAYER ML: Crystal structures of the GluR5 and GluR6 ligand binding cores: molecular mechanisms underlying kainate receptor selectivity. Neuron 45: 539-552, 2005.

MAYER ML: Glutamate receptors at atomic resolution. Nature 440: 456-462, 2006.

MAYER ML, WESTBROOK GL: Permeation and block of N-methyl-D-aspartic acid receptor channels by divalent cations in mouse cultured central neurones. J Physiol 394: 501-527, 1987.

MAYER ML, VYKLICKY L JR, CLEMENTS J: Regulation of NMDA receptor desensitization in mouse hippocampal neurons by glycine. Nature 338: 425-427, 1989.

MAYER ML, ARMSTRONG N: Structure and function of glutamate receptor ion channels. Annu Rev Physiol 66: 161-181, 2004.

MIDGETT CR, GILL A, MADDEN DR: Domain architecture of a calcium-permeable AMPA receptor in a ligand-free conformation. Front Mol Neurosci 4: 56, 2012.

MONY L, ZHU S, CARVALHO S, PAOLETTI P: Molecular basis of positive allosteric modulation of GluN2B NMDA receptors by polyamines. Embo J 30: 3134-3146, 2011.

MONYER H, SPRENGEL R, SCHOEPFER R, HERB A, HIGUCHI M, LOMELI H, BURNASHEV N, SAKMANN B, SEEBURG PH: Heteromeric NMDA receptors: molecular and functional distinction of subtypes. Science 256: 1217-1221, 1992.

MORIYOSHI K, MASU M, ISHII T, SHIGEMOTO R, MIZUNO N, NAKANISHI S: Molecular cloning and characterization of the rat NMDA receptor. Nature 354: 31-37, 1991.

MORLEY RM, TSE HW, FENG B, MILLER JC, MONAGHAN DT, JANE DE: Synthesis and pharmacology of N1-substituted piperazine-2,3-dicarboxylic acid derivatives acting as NMDA receptor antagonists. $J$ Med Chem 48: 2627-2637, 2005.

MOSLEY CA, ACKER TM, HANSEN KB, MULLASSERIL P, ANDERSEN KT, LE P, VELLANO KM, BRAUNER-OSBORNE H, LIOTTA DC, TRAYNELIS SF: Quinazolin-4-one derivatives: A novel class of noncompetitive NR2C/D subunit-selective N-methyl-D-aspartate receptor antagonists. J Med Chem 53: 5476-5490, 2010.

MULLASSERIL P, HANSEN KB, VANCE KM, OGDEN KK, YUAN H, KURTKAYA NL, SANTANGELO R, ORR AG, LE P, VELLANO KM, LIOTTA DC, TRAYNELIS SF: A subunit-selective potentiator of NR2C- and NR2D-containing NMDA receptors. Nat Commun 1: 90, 2010.

NYITRAI G, KEKESI KA, JUHASZ G: Extracellular level of GABA and Glu: in vivo microdialysis-HPLC measurements. Curr Top Med Chem 6: 935-940, 2006.

OGDEN KK, TRAYNELIS SF: Contribution of the M1 transmembrane helix and pre-M1 region to positive allosteric modulation and gating of N-methyl-D-aspartate receptors. Mol Pharmacol 83: 1045-1056, 2013.

PACHERNEGG S, STRUTZ-SEEBOHM N, HOLLMANN M: GluN3 subunit-containing NMDA receptors: not just one-trick ponies. Trends Neurosci 35: 240-249, 2012.

PAPOUIN T, LADEPECHE L, RUEL J, SACCHI S, LABASQUE M, HANINI M, GROC L, POLLEGIONI L, MOTHET JP, OLIET SH: Synaptic and extrasynaptic NMDA receptors are gated by different endogenous coagonists. Cell 150: 633-646, 2012.

PARK-CHUNG M, WU FS, PURDY RH, MALAYEV AA, GIBBS TT, FARB DH: Distinct sites for inverse modulation of N-methyl-D-aspartate receptors by sulfated steroids. Mol Pharmacol 52: 1113-1123, 1997.

PATNEAU DK, MAYER ML: Structure-activity relationships for amino acid transmitter candidates acting at N-methyl-D-aspartate and quisqualate receptors. J Neurosci 10: 2385-2399, 1990.

PETROVIC M, SEDLACEK M, HORAK M, CHODOUNSKA H, VYKLICKY L JR: 20-oxo-5beta-pregnan-3alpha-yl sulfate is a use-dependent NMDA receptor inhibitor. $J$ Neurosci 25: 8439-8450, 2005.

PETROVIC M, SEDLACEK M, CAIS O, HORAK M, CHODOUNSKA H, VYKLICKY L JR: Pregnenolone sulfate modulation of N-methyl-D-aspartate receptors is phosphorylation dependent. Neuroscience 160: 616-628, 2009.

PHILLIS JW, O'REGAN MH: Characterization of modes of release of amino acids in the ischemic/reperfused rat cerebral cortex. Neurochem Int 43: 461-467, 2003.

POPESCU G, AUERBACH A: Modal gating of NMDA receptors and the shape of their synaptic response. Nat Neurosci 6: 476-483, 2003. 
SOBOLEVSKY AI, BECK C, WOLLMUTH LP: Molecular rearrangements of the extracellular vestibule in NMDAR channels during gating. Neuron 33: 75-85, 2002.

SOBOLEVSKY AI, PRODROMOU ML, YELSHANSKY MV, WOLLMUTH LP: Subunit-specific contribution of pore-forming domains to NMDA receptor channel structure and gating. J Gen Physiol 129: 509-525, 2007.

SOBOLEVSKY AI, ROSCONI MP, GOUAUX E: X-ray structure, symmetry and mechanism of an AMPA-subtype glutamate receptor. Nature 462: 745-756, 2009.

SUGIHARA H, MORIYOSHI K, ISHII T, MASU M, NAKANISHI S: Structures and properties of seven isoforms of the NMDA receptor generated by alternative splicing. Biochem Biophys Res Commun 185: 826-832, 1992.

TRAYNELIS SF, HARTLEY M, HEINEMANN SF: Control of proton sensitivity of the NMDA receptor by RNA splicing and polyamines. Science 268: 873-876, 1995.

TRAYNELIS SF, WOLLMUTH LP, MCBAIN CJ, MENNITI FS, VANCE KM, OGDEN KK, HANSEN KB, YUAN H, MYERS SJ, DINGLEDINE R: Glutamate receptor ion channels: structure, regulation, and function. Pharmacol Rev 62: 405-496, 2010.

ULBRICH MH, ISACOFF EY: Rules of engagement for NMDA receptor subunits. Proc Natl Acad Sci USA 105: 14163-14168, 2008.

VANDER AJ, SHERMAN JH, LUCIANO DS: Human physiology: the mechanism of body function. McGraw-Hill, New York, 2001, pp 129, 184.

VILLARROEL A, REGALADO MP, LERMA J: Glycine-independent NMDA receptor desensitization: localization of structural determinants. Neuron 20: 329-339, 1998.

VYKLICKY L JR: Calcium-mediated modulation of N-methyl-D-aspartate (NMDA) responses in cultured rat hippocampal neurones. J Physiol 470: 575-600, 1993.

WATKINS JC, EVANS RH: Excitatory amino acid transmitters. Annu Rev Pharmacol Toxicol 21: 165-204, 1981.

WILLIAMS K: Ifenprodil discriminates subtypes of the N-methyl-D-aspartate receptor: selectivity and mechanisms at recombinant heteromeric receptors. Mol Pharmacol 44: 851-859, 1993.

WILLIAMS K, DAWSON VL, ROMANO C, DICHTER MA, MOLINOFF PB: Characterization of polyamines having agonist, antagonist, and inverse agonist effects at the polyamine recognition site of the NMDA receptor. Neuron 5: 199-208, 1990.

WONG EH, KEMP JA, PRIESTLEY T, KNIGHT AR, WOODRUFF GN, IVERSEN LL: The anticonvulsant MK-801 is a potent N-methyl-D-aspartate antagonist. Proc Natl Acad Sci USA 83: 7104-7108, 1986.

WU FS, GIBBS TT, FARB DH: Pregnenolone sulfate: a positive allosteric modulator at the N-methyl-D-aspartate receptor. Mol Pharmacol 40: 333-336, 1991.

XIA P, CHEN HS, ZHANG D, LIPTON SA: Memantine preferentially blocks extrasynaptic over synaptic NMDA receptor currents in hippocampal autapses. J Neurosci 30: 11246-11250, 2010.

ZUKIN RS, BENNETT MV: Alternatively spliced isoforms of the NMDARI receptor subunit. Trends Neurosci 18: 306-313, 1995.

ZUO J, DE JAGER PL, TAKAHASHI KA, JIANG W, LINDEN DJ, HEINTZ N: Neurodegeneration in Lurcher mice caused by mutation in delta2 glutamate receptor gene. Nature 388: 769-773, 1997. 